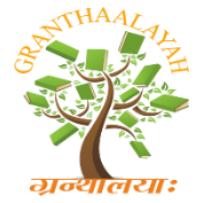

\author{
INTERNATIONAL JOURNAL OF RE
GRANTHAALAYAH \\ A knowledge Repository
}

Social

\title{
NUMBER OF FRIENDS IN SCHOOL AND THE LEVEL OF SELF- CONFIDENCE OF THE STUDENTS
}

\author{
Moneva Jerald ${ }^{1}$, Villegas Honey $\mathrm{Me}^{2}$ \\ ${ }^{1}$ Teacher in Practical Research, Jagobiao National High School, Philippines \\ ${ }^{2}$ Jagobiao National High School, Philippines
}

\begin{abstract}
Friendship is extremely important in people's lives. On the other hand, self-confidence is some of the important variable for the students. Those who have high level of self-confidence tend to have positive outlook on his capacities. This study aims to assess the relationship between the number of friends in school and the level of self-confidence of the students in Jagobiao National High School-Senior High Department. The researcher used a descriptive quantitative design that seeks descriptive information on the relationship between the students' number of friends and their level of self-confidence and also; there are two hundred forty-three respondents. The instrument used for the data collection was a quantitative survey using Likert scale to gather the needed data the researcher adopted a questionnaire from Rosenberg (1965). The data was analyzed through use of weighted mean and chi-square for determining the significant association between the number of friends in school and the level of self-confidence of the students. The findings of the study showed that there was no significant association between the number of friends in school and the level of self-confidence of the students. Generally, having a low or high number of friends does not seem to affect the student's self-confidence.
\end{abstract}

Keywords: Friends; Self-Confidence; Peer Relationship.

Cite This Article: Moneva Jerald, and Villegas Honey Me. (2020). "NUMBER OF FRIENDS IN SCHOOL AND THE LEVEL OF SELF-CONFIDENCE OF THE STUDENTS.” International Journal of Research - Granthaalayah, 8(1), 277-286. 10.29121/granthaalayah.v8.i1.2020.282.

\section{Introduction}

A friend is an individual that a certain person knows and they share common love and experience. Friends is one of the most significant and expensive thing that a person can have in his entire life. People do not need to pretend to be someone else because they can show who they really are when they are around with their friends, a friend is a person who can be trusted. Friends usually help you move on the right path and guide in every step that one takes. They will also help look into the positive side of life. Student's success in social world will enhance if they have a friend that has high level of positive characteristics [1]. 
Self-confidence is an attitude that allows someone to know what the capabilities and weaknesses of a person are [2]. As individual learn and make decisions, they increase specific feedback about their capacity and it builds up the faith in those capacities, with those beliefs described as selfconfidence. Self-confidence is an important factor in improving academic performance and balancing personal life. Being confident about what people have helps draw courage and determination when they are having problems in life. There is a possibility that a student can finish all the tasks given to them if they have enough self-confidence. Student's confidence is very essential tool in their success. In addition, people who have self-confidence usually influence other people easily, as well as they know their limitations and know how to control their own feelings and behavior in a proper way.

Regardless of the students' gender, relationship with their friends is expected to have a high level of self-confidence when it comes to public speaking and academic performance [3]. Having a friend in school or even outside the school helps the student enhance their self-confidence and they also help us deal with our problem. Individuals with socially low related self-confidence are usually credulous [4]. It shows that the relationship with friends and the level of self-confidence especially on the academic performance were both connected variables for the students.

The study wants to know the significant relationship between the number of friends in school and the level of self-confidence of the students in Jagobiao National High School- Senior High Department.

\section{Theoretical Background}

This chapter presents the theory that will support the study. The looking-glass self-theory is a social psychological idea made by Charles Horton Cooley in 1902 that states how people develop their self-image through reaching out, interacting, or socializing with those people that surrounds them. This theory is described as, our reflection of how we think we appear to others. To explain further, it means that a person imagines his self-base on how other people view him. The theory of looking glass self is formed as an evaluation of the response of other people in the society. Cooley's theory also focuses on the active participation of the individual in forming his or her selfconcept and the process in motivating behavior and social interactions.

In connection to this, having a friend is very important in understanding the process of the theory of looking glass self. Individuals select his or her own friend based on their characteristics its either they have the same characteristics or not. Individuals form themselves depending on other people's perception, which leads to reinforce other individuals' point of view in them. Those individual that have negative quality of friends' results to depression to the point that his self-esteem will be based on the point of view of his friends [5]. People shape themselves based on what other people see and confirm other people's opinion on themselves. If a person is dependent with other individual's perception they might lose or gain self-confidence depending on the situation given. For instance, a person is reporting in front, if a person notice positive reactions, such as smiling and nodding their head, the person who is reporting might develop his self-confidence. However, if the person notices negative response such as lack of interest, the self-confidence of the person might get low. In addition, the theory shows that individual has an active role to play in that they perceive how 
others see them. The identity of a person is the result of learning to see him through what he perceives to be the perception of others.

\section{Statement of Purpose}

The study intends to assess the relationship between the number of friends in school and the level of self-confidence of the students.

Specifically, the study seeks to answer the following sub problem:

1) What is the number of friends of a senior high school student?

2) What is the level of self-confidence of the senior high school student?

3) Is there an association between number of friends in school and the level of self-confidence of the students?

\section{Hypothesis}

Null Hypothesis: There is no association between the number of friends in school and the level of self-confidence of the students.

Alternative Hypothesis: There is an association between the number of friends in school and the level of self-confidence of the students.

\section{Review of Related Literature and Studies}

This section is composed of review of related literature and studies from different authors and sources. The objective of this chapter is to support the study.

Adolescence is a period in which the person transcends from childhood to adulthood. In this stage, individual changes the way how they think, act, and feel and also they will develop how to communicate and make friends with other people. In this century, social interaction is indispensable. Socialization is very essential in terms of diminishing adolescents' intimate and social loneliness [6]. One of the predictions that can cause loneliness is having lesser friends in school and outside the school premises. Students who have good social relation might have increased in self-awareness and cooperation [7]. When socializing, most of the people gain friends and students might gain new friends if they will build confidence in standing up for what they think is true or right [8]. Students who have skills in communicating and forming friends are more likely to develop positive relationships.

Friendly relationship is beneficial among students [9]. If a slow learner student will have a friend that is academically inclined, he tends to be influenced and he will have the courage to study hard [10]. In addition, teenagers who feel that they are supported and cared by his friends tend to be more interested to study and pursue what they really want in life [11]. Some students might acquire intellectual benefits from their peers who have good academic skills and abilities; others might suffer from negative outcomes of social comparison. On the contrary, stated that adolescence who have a friend that have a higher level of risk behavior may be influence and they might face danger because it has been distinguish that friends has the greatest influence in any involvement in such characteristics [12]; [1]. 
One of the best predictor of adjustment is having a good quality of characteristics in friendship [13]; [14]. Individual who maintains honesty in friendship can also help maintain self-esteem [15]. Youth who have the skills to make new friends are more likely to be able to adjust and adapt easily in diverse culture of other people that surrounds them. Youth who have a higher amount of satisfaction tends to have a close relation with their family and friends [16]. On the other hand, individual who have negative quality of friend's results to depression to the point that his selfesteem will be based on the point of view of his friends [5].

It has been observed that physical appearance is important in gaining new friends' body image is not essential in building new friend [17]. Making friend is not about pleasing other people with your physical appearance but it is how you deal or approach with them. Students might decrease self-esteem and feel lonely when they are rejected with their friends [18].

Confidence is an attitude that a person must have acquired because it is very important especially to those who are in adolescence stage. Self-confidence is an ability to foresee his own behavior or capabilities. Adolescence who has self-confidence generally likes his or herself [4].

Students' age and class status are some of the factor that can affect student's confidence and achievement [19]. Negative behavior should be avoided so that higher level of self-confidence and academic achievements can be attaining [20]. Guidance officer is one of those who can improve student's self-confidence and talent for achieving goals in life [21]. On the other hand, students' self-confidence and academic achievements will be high as long as their self-efficacy is high [22]. Moreover, collaborative learning model is effective in enhancing self-confidence [23]. Oral recitation should be implemented inside the classroom so that the students' performance and confidence increase [24]. In addition, those who trust their own abilities are more likely to have higher ratings when it comes to public speaking than those students who does not have enough self-confidence and not willing to communicate [25].

In addition, a strong bound of friend among teenagers assumes to have a vital job in talking in front of other people [3]. Students who have high level of self-confidence are more likely to have the courage to speak up in front of many people [26]. On the contrary, those students who have low level of self-confidence are afraid to speak in front and they are not certain with their abilities. When students are engaged with their class, their perception towards learning language will improve and they will obtain self-confidence [27]. Learning techniques and self-confidence are one of the influential factors that can affect the students learning [28].

Locus of control refers to the adolescents' perception of the main cause of event and there is no significant association between students' locus of control and self-confidence in relation to the medium of instruction [29].

It is very essential for nurses to have enough self-confidence so that they can act accordingly, while having low self-confidence can cause more errors in work and it can lead to anxiety [2]. In connection to this, students should have enough confidence in order for them to have better academic achievements and for them to avoid anxiety \& depression. To lessen depression, creating stress management techniques such as positive self-task is prescribed to diminish symptom level 
and increase self-confidence to promote a less debilitative interpretation of the symptom response [30].

\section{Materials and Methods}

\section{Design}

The research study used a descriptive quantitative design of the variable to determine the association of the number of friends in school and level of self-confidence of the students.

\section{Environment}

The researcher conducted a research in Jagobiao National High School. Since the school has two departments which is the Junior High Department and Senior High Department, the researcher decided to conduct a research in Senior High Department so that the researcher could easily ask permission to the teacher and as well as to the students and the researcher could easily gather the data.

\section{Respondent}

The researcher chose 240 respondents in a random sample that comes from Senior High School Department of Jagobiao National High School. The Senior High School Department compose of 8 sections, the Science Technology Engineering and Mathematics 11 (STEM), Accountancy Business and Management 11\&12 (ABM), Humanities and Social Sciences 11\&12 (HUMSS), General Academic Strand 11\&12 (GAS), and Technical-Vocational and Livelihood 11 (TVL).

\section{Instrument}

The researcher used a Likert scale as a survey questionnaire that consist of two parts. Part 1 is all about the number of friends that the students have in school. The respondents will fill out a blank and they will indicate how many friends they have in school. Part 2 is all about the level of selfconfidence of the students. The researcher adopted a tool from Rosenberg (1965) that consists of 10 items. The Likert scaling questionnaire is a type of rating that will measure the students' level of self-confidence and number of friends of the respondents. The respondents are asked to rate the following item on a level of agreement from strongly agree to strongly disagree.

\section{Data Gathering Procedure}

Before conducting a survey, the researcher made a transmittal letter to ask permission from the principal, teachers, and students in every classroom. The researcher used a Likert scaling as a survey questionnaire that intends to answer the number of friends and level of self-confidence of the students in Jagobiao National High School- Senior High School Department. The researcher chose 250 students as a respondent and they would be given 2-5 minutes to answer the following questions. After that the researcher will collect and analyze the data given.

\section{Statistical Treatment}

To interpret the data effectively, the researcher used the following statistical tool. The weighted mean is used to calculate the average mean of the level of self-confidence and to identify if the number of friends has an influence towards the level of confidence of the student. Chi-square is also used for testing the relationship between the two variables, which is the number of friends and 
the level of self-confidence. Chi-square is a hypothesis test where in the sampling distribution for the test statistics is a Chi-squared distribution when the null hypothesis is true.

\section{Results and Discussions}

Table 1: Profile of Students in their Number of Friends

\begin{tabular}{|l|c|c|}
\hline Number of Friends & Number of Students & Percentage \\
\hline $0-60$ & 220 & $91.67 \%$ \\
\hline $61-120$ & 15 & $6.25 \%$ \\
\hline $121-180$ & 2 & $0.83 \%$ \\
\hline $181-240$ & 2 & $0.83 \%$ \\
\hline $241-300$ & 1 & $0.42 \%$ \\
\hline Total & 240 & $100.00 \%$ \\
\hline
\end{tabular}

The table above shows the frequency of the students' number of friends in school. The first highest has a frequency of 220 which has a number of 0 to 60 friends followed by a frequency of 15 with a number of 61 to 120 friend. On the other hand, the first lowest has a frequency of 1 which indicate that students have 241 to 300 friends followed by a frequency of 2 which indicates that respondents have 121 to 240 friends.

Having a friend is very essential in people's life. Suggest that students who are able to make new friends are more likely to have positive relationships towards their classmates and they can easily adapt to any changes than those students whose skill in making new friends are not yet develop [14].

Table 2: Students' Self-confidence

\begin{tabular}{|l|c|c|}
\hline Indicators & $\begin{array}{c}\text { Weighted } \\
\text { Mean }\end{array}$ & Interpretation \\
\hline On the whole, I am satisfied with myself. & 3.22 & Agree \\
\hline At times, I think I am no good at all. & 2.71 & Agree \\
\hline I feel that I have a number of good qualities. & 2.98 & Agree \\
\hline I am able to do things as most other people. & 2.89 & Agree \\
\hline I feel do not much to be proud of. & 2.66 & Agree \\
\hline I certainly feel useless at times. & 2.61 & Agree \\
\hline I feel that I'm a person of worth, at least on an equal plane others. & 2.95 & Agree \\
\hline I wish I could have more respect for myself. & 3.16 & Agree \\
\hline All in all, I am inclined to feel that I am a failure. & 2.48 & Agree \\
\hline I take positive attitude towards myself. & 3.31 & Agree \\
\hline OVERALL WEIGHTED MEAN & 2.90 & Agree \\
\hline
\end{tabular}

Legend: 1.00-1.75=Strongly Disagree, 1.76-2.50= Disagree, 2.51-3.25= Agree, 3.26-4.00= Strongly Agree 
From the table above, it shows that the 10 indicators had a three highest and lowest weighted mean that has an interpreted of agree. The first highest has a weighted mean of 3.31 which states that students take positive attitude towards themselves, the second highest has a weighted mean of 3.22 which indicates that students are satisfied with their selves, and the last highest has a weighted mean of 3.16 which states that students wish they could have at least enough self-confidence. The first lowest weighted mean is 2.48 , which indicate that students are inclined to feel that they are a failure; the second lowest weighted mean is 2.61 that state students certainly feel useless at times. Lastly, the lowest weighted mean is 2.66 , which states that the respondents feel they do not much to be proud of. While the overall weighted mean of the second variable interpreted as agree and has a weighted mean of 2.90 .

Self-confidence is defined as an individual's recognition towards their own beliefs, abilities, and being aware of what he feels [4]. Self-confidence is very essential especially in dealing with other people and making new friends [22].

Table 3: Students' Level of Self-confidence

\begin{tabular}{|l|c|c|c|}
\hline Range & Frequency & Percentage & Interpretation \\
\hline $0-10$ & 0 & $0 \%$ & Not confident at all \\
\hline $11-20$ & 0 & $0 \%$ & Slightly confident \\
\hline $21-30$ & 165 & $68.75 \%$ & Confident \\
\hline $31-40$ & 75 & $31.25 \%$ & Highly confident \\
\hline Total & 240 & $100 \%$ & \\
\hline
\end{tabular}

This table indicates the students' level of self-confidence. Adolescence who has self-confidence usually like his or her confidence [4]. Out of 240 respondents, there are 165 who said that they have enough self-confidence. On the other hand, there are 75 who said that they have high level of self-confidence. Students who have high level of self-confidence are more likely to have the courage to speak up in front of man are more likely to have the courage to speak up in front of many people [26].

Table 4: Number of Friends and Level of Self-confidence

\begin{tabular}{|l|c|c|c|}
\hline & Value & df & Asymp. Sig. (2-sided) \\
\hline Pearson Chi-Square & $3.564^{\mathrm{a}}$ & 4 & .468 \\
\hline Likelihood Ratio & 4.887 & 4 & .299 \\
\hline Linear-by-Linear Association & 1.257 & 1 & .262 \\
\hline N of Valid Cases & 240 & & \\
\hline
\end{tabular}

The finding above shows that there is a no significant association between the two variables the number of friends in school and students' level of self-confidence. The variables which is the $\mathrm{p}$ value is greater than the alpha $(\mathrm{p}=.468<.05)$ so the result is failed to reject. This means that the number of friends in school and the level of self-confidence of the students do not have a significant association. On the contrary, having high number of friends among teenagers plays a vital role in enhancing their self-confidence in relation to public taking like debates or speech [3]. Receiving text messages coming from your family, friends and school or community is one of the important factors that can enhance self-confidence [27]. On the other hand, teenagers who seldom receive messages with their peer can result to low level of self-confidence [3]. 


\section{Conclusion}

Friendship is all about how someone accepts you and believes in you. In order to build a strong and friendly relationship, one should have loyalty, trust, honesty and love. Having a friend can improve someone's life. Managing how to carry out emotion and how to interact with other people are some of the benefits of having friends. Based on the research result it can be concluded that despite of having low number of friends, it never made them decrease in self-confidence especially in dealing with other people. Friends and self-confidence is very important in people's lives especially on adolescence stage. The number of friends is not the basis of having a high level of self-confidence because after all high level of self-confidence can be obtain by having trust or belief in one's self. Overall, there is no association between the number of friends in school and the level of self-confidence of the students of Jagobiao National High School.

\section{Recommendation}

The following are the recommendations of the researchers based on the data gathered:

1) The school administrator and teachers should encourage students to have enough selfconfidence.

2) Parents should monitor the behavior of their children's chosen friends because the behavior of his friends might influence him.

3) Students should trust their own abilities and beliefs so that they can make all the things that are needed to be done.

\section{Limitation of The Study}

In this study, there are various limitations. First, the study only focuses on the senior high school students which results to few respondents and might not represent the whole idea. Second, this study only focuses on what will be the effect of having a low or high friend to the self-confidence. Lastly, the future researcher may include a wider sample size for the study to be more reliable. In addition, they should include student's characteristics when it comes to self-confidence.

\section{References}

[1] Brendt, T. (2002). Friendship quality and social development. Current Directions in Psychological Science, 11(1), 7-10. https://doi.org/10.1111/1467-8721.00157

[2] Martins, J., Baptista, R. Coutinho, V., Mazzo, A., Rodrigues M. \& Mendes, I. (2014). Selfconfidence for emergency intervention: Adaptation and cultural validation of the self-confidence scale in nursing students. Revista Latino-Americana De Enfermagem, 22(4), 555-561. Doi:10.1590/0104-11693128.2451

[3] Gorsy, C. \& Panwar, N. (2015). Study of self-confidence as a correlate of peer-relationship among adolescents. International Journal of Education \&Management Studies, 5(4), 298-301. https://www.researchgate.net/publication/294719426

[4] Greenacre, L., Tung, M. \& Chapman, T. (2014). Self-confidence and the ability to influence. Academy of Marketing Studies Journal, 18(2), 169-180.https://www. researchgate. net/publication/286318041_Self_confidence_and_the_ability_to_influence 
[5] Cambron, M., Acitelli, L. \& Steinberg, L. (2009). When friends make you blue: The role of friendship contingent self-esteem in predicting self-esteem and depressive symptoms. Personality and Social Psychology Bulletin, 36(3), 384-397.Doi:10. 1177/ 0146167209351593

[6] Cheng, H. \& Furnham, A. (2002). Personality, peer, and self- confidence as predictors of happiness and loneliness. Journal of Adolescence, 25, 327-339.Doi: 10.1006/yjado.475

[7] Mosha M. (2017). The influence of peer group on academic performance of adolescent students in secondary schools in Tanzania. Research Journal of Educational Studies and Review, 3(1), 18-26. http://pearlresearchjournals.org/journals/rjesr/index.html

[8] Schuh, M., Sundar, V. \& Hagner, D. (2015). Friendship is the ocean: Importance of friendship, acceptance, and leadership in the transition to adulthood. Hammill Institute on Disabilities, 38(3), 152-161. Doi:10.117/21651434 14528031

[9] Gottfried, M., Owens, A., Williams, D., Kim, H. \& Musto, M. (2017). Friends and family: A literature review on how high school social groups influence advanced math and science course taking. Educational Policy Analysis Achives, 25(62). http://dx.doi. org/10.14507/epaa.25.2857

[10] Olalekan, A. of (2016). Influence of peer group relationship on the academic performance of students in secondary schools. Global Journal of Human-Social Science: An Arts \& HumanitiesPsychology, 16(4), 35-47. https://pdfs.semanticscholar.org/

288f/c56d2a6eb36ed11a35c474c4e41424074a10.pdf

[11] Tome, G., De Matos, M., Simoes, C., Camacho, I. \& Diniz, J. (2012). How can peer group influence the behavior of adolescents: Explanatory model. Global Journal of Health Science, 4(2), 26-35. https://www.researchgate.net/publication/233382063

[12] Demir, M. \& Urberg, K. (2004). Friendship and adjustment among adolescents. Journal of Experimental Child Psychology, 88, 68-82. Doi: 10.1016/j.jecp.2004.02.006

[13] Aikins, J., Bierman, K. \& Parker, J. (2005). Navigating the transition to Junior High School: The influence of pre-transition friendship and self-system characteristics. Social Development, 14(1), 1-19. https://www.research gate.net / publication/227807410

[14] Okada, R. (2012). Friendship motivation, aggression, and self-esteem in Japanese undergraduate students. Journal of Psychology, 3(1), 7-11. http://dx.doi.org/10.4236/psych.2012.31002.

[15] Bakalim, O \& Karckay, A. (2016). Friendship quality and psychological well-being: The mediating role of perceived social support. International Online Journal of Educational Sciences, 8(4), 1-9. https://dx.doi.org/10.15345

[16] Tzafettas, M. (2009). The relationship between friendship factors, body-image concern and restrained eating. Aristotle University Medical Journal, 36(2), 53-64. https:// ejournals.lib.auth.gr/aumj/article/view/4735

[17] Mujiyati, M. \& Adiputra, S. (2018). Influence of peer groups to the self-esteem of Lampung and Javanese students. International Journal of Psychology and Educational Studies, 5(1), 15-22. http.//dx.doi.org/10.17220/ijpes.2018.01.003

[18] Kunhertanti, K. \& Santosa, R. (2018). The influence of students' self-confidence on Mathematics learning achievement. Journal of Physics: Conference Series, 1-6. Doi: 10.1088/174$6596 / 1097 / 1 / 012126$

[19] Tuncel, H. (2015). The relationship between self-confidence and learning Turkish as a foreign language. Academic Journals, 10(18), 2575-2589. Doi: 10.5897/ERR2015.2445

[20] Verma, R.\& Kumari, S. (2016). Effect of self-confidence on academic achievement of children at elementary stage. Indian Journal of Research, 5(1), 181-183. https://www .worldwidejournals.com/paripex/fileview/January_2016_1453528758_99.pdf

[21] Sar, A., Avcu, R. \& Isiklar, A. (2010). Analyzing undergraduate students' self confidence levels in terms some variables. Procedia Social and Behavioral Sciences, 5, 1205-1209. https://www.researchgate.net/publication/230818363 
[22] Nurhayati, N., Rosmaiyadi, R. \& Buyung, B. (2017). Efforts to improve student's self-confidence using collaborative learning model. Jurnal Pendidikan Matematika Indonesia, 2(2), 57-62. https://www.researchgate.net/publication/320718457

[23] Doqaruni, V. (2014). A quantitative research on promoting confidence in a foreign language classroom: Implications for second language teachers. Inquiry in Education, 5(1),1-18. https://digitalcommons.nl.edu./ie/vol5/issl/3

[24] Gurler, I. (2015). Correlation between self-confidence and speaking skill of English language teaching and English language and literature preparatory students. Curr Res Soc Sci, 1(2), 14 -19. https://www.academia.edu/12743140/Correlation_between_

Selfconfidence_and_Speaking_Skill_of_English_Language_Teaching_and_English_Language_a nd_Literature_Preparatory_Students

[25] Al-Hebaish, S. (2012). The correlation between general self-confidence and academic achievement in the oral presentation course. Theory and Practice in Language Studies, 2(1), 60-65. Doi: 104304/tpls.2.1.60-65

[26] Martinez, E. \& Villa, O. (2017). A quantitative study of self-confidence in learning English as a foreign language. Academia Journal of Educational Research, 5(2), 024-025. Doi: 10.15413/ajer.2017.0302

[27] Sihotang L., Setiawan, D. \& Saragi, D. (2017). The effects of learning strategy and self-confidence toward student's learning outcomes in elementary school. Journal of Research \&Method in Education, 7(4), 65-72. Doi: 10.9790/7388-0704016572

[28] Vanaja, Y. \& Geetha, D. (2017). A study on locus of control and self-confidence of high school students. International Journal of Research Granthaalayah, 5(7), 598-602. Doi: 10.5281/zenodo.841186

[29] Mellalieu S., Neil, R. \& Hanton, S. (2006). Self-confidence as a mediator of the relationship between competitive anxiety intensity and interpretation. Research Quarterly for Exercise and Spot, 77(2), 263-270.https://www.researchgate.net/publication/6889474

[30] Rosenberg, M. (1965). Society and the adolescent self-image. Princeton University Pres. https://www.yorku.ca/rokada/psyctest/rosenbrg.pdf

*Corresponding author.

E-mail address: freezingfire1979@gmail.com 